\title{
Pénzföldrajz a Geopolitikában. Európai hatalmak amerikai geopolitikája a pénzügyek tükrében
}

\section{Monetary Geograpgy in Geopolitics and Geopolitics of European Powers on American soil as reflected by Finances}

\author{
Dr. habil Békési László PhD. közgazdász, szociológus, geopolitikus
} bekesi@hotmail.com

Initially submitted March 27, 2020; accepted for publication Apr.28, 2020

\begin{abstract}
This paper examins the expansion, existence and withdrawal of European powers on ad from the American Continent by following the circulation of their coins. The present research is focusing on the variety of strategies of European powers, during their domestic crises when they rethinked their relations toward their American colonies. We can see a colourful picture of those changes when following their coins in monetary circulations. Coinage produces excellent symbols since it represents the state power controlling a territory towards both their own citizens and foreign environment.
\end{abstract}

Kulcsszavak: európai hatalmak, gyarmatok, jelenlétét, kivonulás, érmék és pénzek elemzése

Keywords: analysis of European powers, colonies, presence, withdrawal, coins and money

\section{Bevezetés}

Az amerikai kontinens a Sir Halford Mackinder által 1904-ben felvázolt elméletével összhangban az európai tengeri hatalmak befolyási övezetévé vált az elmúlt fél évezredben ${ }^{1}$. A kolumbiánus kor, amikor a hajózó népek erőfölénybe kerültek a szárazföldi hatalmakkal szemben tökéletes, modell értékü lenyomatát hagyta az amerikai kontinensen és a karib szigetvilágban. Az európai gyarmati függés már a múlté, azonban a szimbolikus kötődés még számos módon igazolható, megfogható. Az európai hatás leglátványosabban talán az épített környezetben, valamint az angol, francia, spanyol, portugál, holland nyelvben (és ezek keveredésében) fogható meg. „Apró”, azonban igen erős szimbolikus kötődésre utalnak az amerikai kontinensen valaha és jelenleg használt fémpénzek is. Ebben a munkában ezt a függést kutatva elsősorban Amerika és Európa kapcsolatait vizsgálom az amerikai kontinensen korábban, illetve napjainkig használt forgalmi érmek elemzésével. Míg kutatásom első szakasza Latin-Amerikára helyezte a hangsúlyt, jelen írásomban a kutatás területi lehatárolását az amerikai kontinens és a Karib-szigetek hozzáadásával bővítettem, mivel az orosz pénzforgalom az egész világon egyedülálló ötletekkel és alapanyaggal müködött, illetve a brit és francia jelenlét Észak-Amerikában és a kontinens más részein is megfigyelhető, illetve a hajózó Európa szinte teljesen leképződik a Karib-térségben és így a térség fémpénz-forgalmán is.

A téma, a forgalmi pénzek kutatása sajnálatosan igen kevés figyelmet kap, pedig az éremkibocsátás, tervezés tökéletes vizsgálódási területet nyújt a nemzetközi kapcsolatok, vagy éppen a pénzügyek kutatóinak, demográfusoknak, szociológusoknak, történészeknek, földrajzosoknak. A mivel fizetnek valahol? -kérdés megválaszolása fontos információt adhat, utalhat a tér uralásának rejtett dimenzióira, a kapcsolathálóra, a kereskedelmi forgalomra és a partnerekre, a függések rendszerére és dinamikájára, vagy éppen az európai kontinensen zajló eseményekre, konfliktusokra, tágabb értelemben a gazdaság, még bővebben a társadalom általános állapotaira. A térségben számos furcsa pénzrendszer élt és él, akár egymással párhuzamosan is.

\footnotetext{
${ }^{1}$ Mackinder, Halford: The Geographical Pivot of History. The Geographical Journal. Vol. 23. (1904) no. 4. $421-437$. http://www.kaleidoscopehistory.hu dr.habil Békési László PhD
} 
Kaleidoscope

Ugyanakkor pl. Franciaország St. Barthélemy (Szent Bertalan) karib-tengeri szigetén az árszintre utal az a jótanács, amit egy útikönyv gyakorlati része fogalmaz meg: ide legjobb dollár, euró, vagy bármilyen pénznem helyett egyszerüen aranyrudakat hozni².

Aggasztó, hogy egy nemzetközi kapcsolatokat, történelmet, pénzügyeket, iparmüvészetet, társadalomföldrajzot, vagy akár kertészetet tanult szakember tanulmányai során sosem találkozik a konkrét régi bankjegyekkel, érmékkel, holott ez igen látványosan segíthet az oktatásban minden tudomány esetében. Például egy hazai agrármérnök a mai napig folyamatosan használja az aranykorona fogalmát egy adott terület jövedelemtermelő képességének meghatározásához, de sosem látta hogyan nézett ki egy osztrák, vagy magyar arany húszkoronás, mettől meddig használták, mekkora volt a súlya, mit lehetett érte kapni, egy művészettörténész nem tudja, hogy a két világháború közti bolgár érméket magyar éremmüvész, Berán Lajos tervezte és Budapesten készültek, egy földrajzos nem tudja, miröl híres Körmöcbánya, egy nemzetközi jogász nem tanulta hogyan függ mindez össze a nemzetközi kereskedelemmel és emberi jogokkal ${ }^{3}$, és egy (off shore) pénzügyes, vagy tőzsdeszakértő sosem látott kajmán-szigeteki dollárt.

\section{A munkában felvetett kérdések és a módszertan}

Milyen kapcsolat mutatható ki az anyaország és az amerikai kontinensen lévő gyarmati, vagy egyéb területei között a használt pénzek elemzésén keresztül?

Az amerikai éremkibocsátást vizsgálva hogyan volt és föleg hogyan van jelen ma Európa az Újvilágban? Hogyan változik nyugodt, illetve háborús, konfliktusos időkben a gyarmati pénzkibocsátás és ezen keresztül hogyan érthetjük meg a gyarmat és az anyaország kapcsolatának fordulópontjait és dinamikáját?

Ezen kérdésekre adott válaszok egy új dimenzióban világítják meg azt a történelmi eseménysort, korszakot, amelyet imperializmusnak nevezett és nevez ma is a történetírás.

A kutatás módszertana az irodalomfeldolgozás mellett a konkrét kibocsátott és forgalomba került érmék (esetleg bankjegyek) rendszerezése, bemutatása, felirataik, éremképük és pénzegységük neveinek elemzése jelentős részben a szerző gyüjteményének felhasználásával, kisebb részben szakirodalmi munkák adatai alapján. ${ }^{4} \mathrm{Ne}$ feledjük, hogy egy pénztárcában, zsebben, nyakban hordott tarsolyban lapuló néhány érme a legközvetlenebb kapcsolat a polgár és az államhatalom között a mindennapokban. Továbbá a fizetőeszköz fejezi ki két polgár között az azonos közösséghez tartozást, az azonos értékrendet, vagy annak közös minimumát. Az indokínai háború után Párizshoz lojális vietnámi törzseket telepítettek át Francia Guyanára ${ }^{5}$. Első nekifutásra furcsa elképzelni, hogy ugyanazon a napon amikor Párizsban euróval fizetnek, egy ilyen törzs öserdei mezítelen lakosai -ahogy a franciák mondják az európai Amazóniában- a helyi kisboltban egy Cacao nevü kis falu közelében szintén euróval fizetnek es mindkét vásárlás francia nyelven zajlik. Még furább, ha tovább gondoljuk, hogy a franciabarát vietnámiak azért települtek ide, mert a harmincas években még elítélt franciaellenes lázadó vietnámiakat hoztak ide gyakorlatilag kényszermunkára egy Inini nevü körzetbe $^{6}$ (ami szintén saját bélyeget kapott). És hogy Guyana Dyerfus és Charriére (Pillangó) kényszerlakhelye is itt volt és tulajdonképpen a cári szibériai fegyenctelepek előképe mindez, egy eltérő

\footnotetext{
${ }^{2}$ Runge, Jonathan: French Caribbean. Boston, 2005.

${ }^{3}$ Komanovics, Adrienne: Towards a Normative Framework: The UN Treary on Transnational Corporations, Other Businesses and Human Rights.Corvinus Journal of International Affairs. Vo. 3. no. 3 (2018) pp 28-42.DOI:

https://doi.org/.10.14267/cojourn.2018v3n304

${ }^{4}$ Schön, Günter: Weltmünzkatalog vol. I-II. München, 1985

${ }^{5}$ Békési, László: Analysis of Security Issues in French Guiana by the Eyes of a Recce. Tradecraft Review. Periodical of the Scientific Board of Military Security Office. 2. Special Issue (2014) pp. 53-64.

${ }^{6}$ Björn Berge: Nowherelands. An Atlas of Vanished Countries 1840-1975. New York, 2017. http://www.kaleidoscopehistory.hu dr.habil Békési László PhD
} 
éghajlatra és távolságra, mint büntetést nehezítő, embert megtörö és megsemmisítő tényezőkre építő kegyetlen rendszer ${ }^{78}$.

Továbbá része a kutatásnak egy saját fejlesztésü, három és fél évtizede használt módszer, amit mikro kutatásnak neveztem el. Ennek lényege, hogy egy konkrét helyszínre érkezve a tárgyak szemrevételezésével nagy valószínüséggel leírható az adott terület története, birtoklási (államitól az egyén szintjéig) viszonyai, konfliktusai. Ilyen árulkodó, előző korokra, uralmi viszonyokra, nyelvekre, népekre, gyártóra, vagy akár harcra utaló feliratokat, dekódolható üzeneteket hordoznak a sínek, csatornafedelek, téglák, egy „Gyarmati Líceum" bélyegzésü tányértöredék, egy ezüst bokalánc, amit a felszabadításkor kapott egy rabszolga hajdani gazdájától 1848-ban A nyomolvasás szinte korlátok nélküli adathalmazt tár elénk. De az elszórt aprópénzek és töltényhüvelyek is a történelem hírmondóivá válnak. Ez a módszer eltér a régészettől, hiszen nem egyedi és nem nagyon régi és nem értékes tárgyakat keres, hanem egyszerü, tömegesen előfordul, szinte értéktelen tárgyakat. Gyerekkoromban megrökönyödve vettem észre egy középkori templom melletti ásatásnál, hogy a régészek megvetett hulladékként halmozzák fel a gödör szélén a második világháborús német és szovjet töltényhüvelyeket, holott ezek is beszélnek a hely lényegéről, még akkor is, ha nem keresett középkori réteg történetét mesélik el. A karib térségben tett eddigi 6 kutatóutam ide vonatkozó mikro kutatási eredményeit is bemutatom részben.

$\mathrm{Az}$ egyes európai hatalmak jelenlétét az amerikai kontinensen északról dél felé haladva, a hajdani gyarmatosítók szerinti csoportosításban veszem sorra.

\section{A brit jelenlét az amerikai kontinensen}

Az amerikai kontinenst „tetőtől talpig” behálózta a brit gyarmatbirodalom. Ennek nyomait a mai pénzhasználat is tükrözi Kanadától a Falkland-szigetekig. (3.ábra), A Brit Birodalom a változatosságot preferálta az éremkibocsátásban, ezzel is érzékeltetve a birtokában lévő területek nagy méretét és számosságát, a „területek geopolitikai felhalmozását”. Viktória királynő idején például Kanadában eltérő érmeket használtak a terület megnevezésével és teljesen eltérő éremképpel New Fundlandon (1. ábra)Új Skóciában, a Prince Edward-szigeten, New Brunswickben, Québec-ben (itt francia köriratokkal), vagy éppen Felső Kanadában (2.ábra).

\footnotetext{
${ }^{7}$ Békési, László: KGB and Soviet Security Uniforms and Militaria 1917-1991. Marlborough, 2002.

${ }^{8}$ Békési László: Cári időkből visszatérö patrióta és nacionalista elemek és szimbólumok a Nagy Honvédö Háború idején. PhD Értekezés. 2004. 


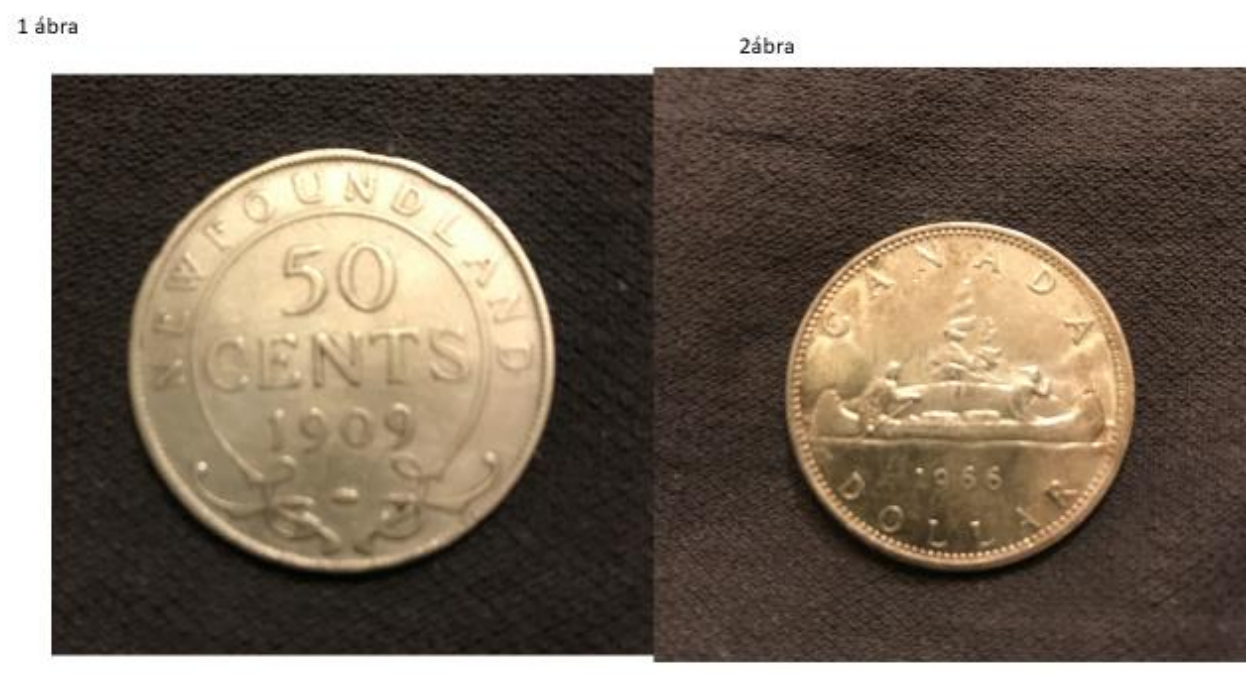

1.ábra: Tetőtől talpig, brit érdekszféra 1. New Foundland 50 cent, VII. Edward király, 1909. 2.ábra: Tetőtől talpig, brit érdekszféra 2. Kanada, egy dollár, Erzsébet királyné, 1966.
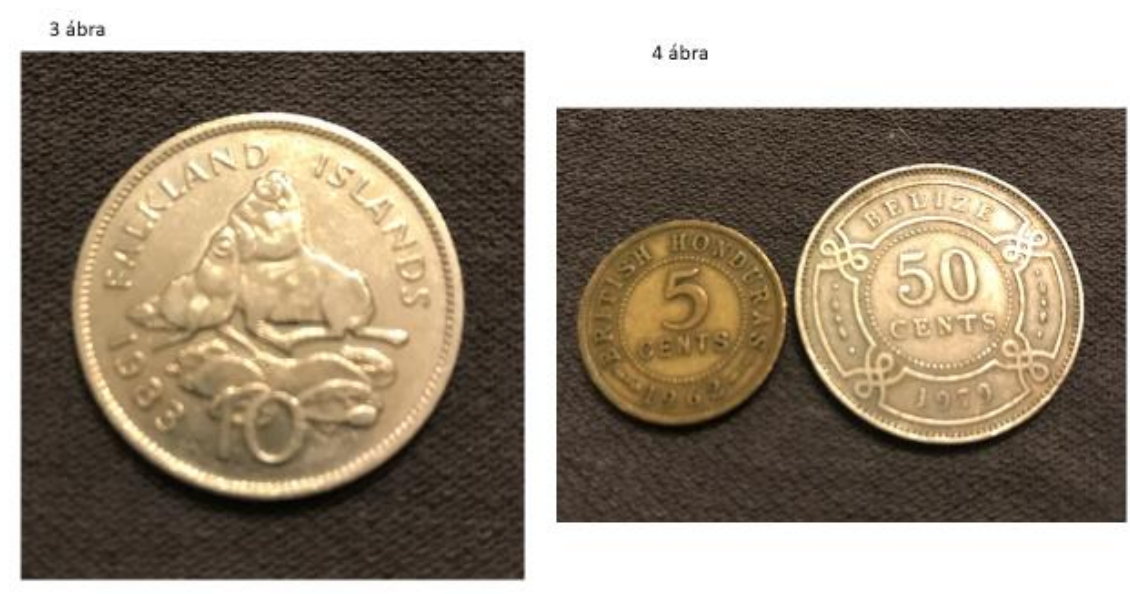

3.ábra: Tetőtől talpig, brit érdekszféra 3. Falkland-szigetek. 1983. 4.ábra: Brit Honduras és Belize

Dél felé haladva a kontinensen a mindenkori brit uralkodó képe díszítette, vagy díszíti az érmeket (és bankjegyeket, bélyegeket, hivatalokat, tantermeket stb.) Brit Hondurasban (a mai Belize) (4. ábra), a KeletKaribi Államokban, a Brit Virgin-szigeteken(5. ábra), Jamaicában, a Kajmán-szigeteken, Bermudán, a Bahamákon, Brit Guyanában (Ma Guyana)(6.ábra), vagy éppen a kontinens legdélibb csücske közelében a Falkland-szigeteken. 
Kaleido scope
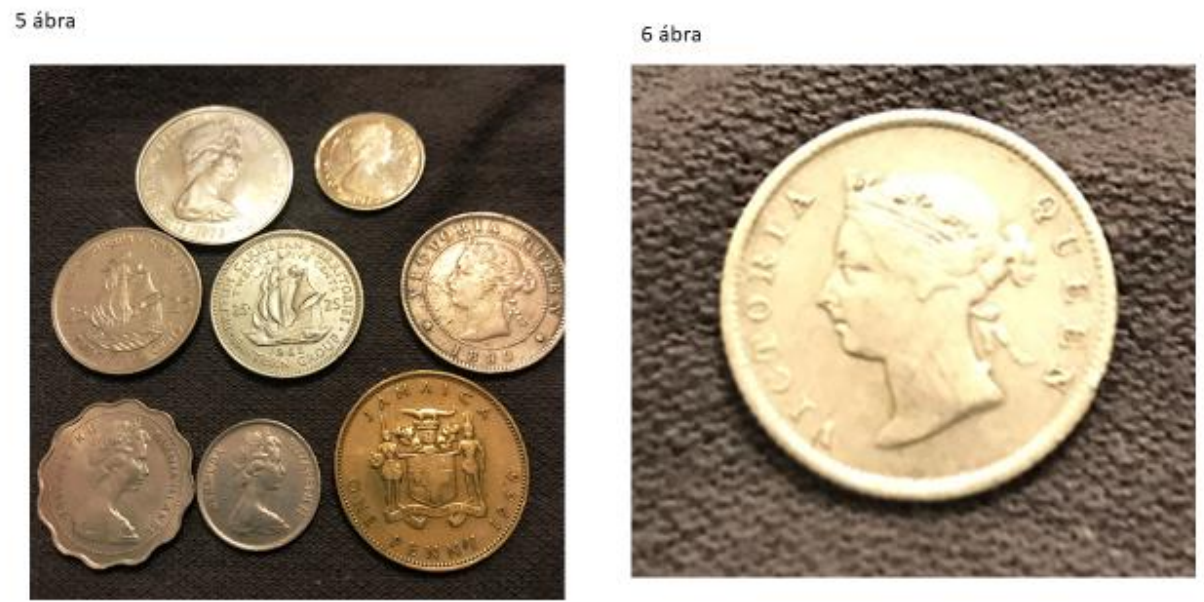

5.ábra: Karibi brit kavalkád: Brit Virgin-szigetek, Cajmán-szigetek, Kelet-Karibi Államok, Brit Karibi Területek, Bahamaszigetek, Bermuda és két jamaicai érme Viktória és Erzsébet idejéből.

6.ábra: Brit Guyana és Nyugat India 4 penny, Viktória királyné idejéből. 1891.

A kelet-karibi dollárt használó államok közül érdemes megemlíteni Anguilla szigetét. Itt 1967-ben megtudták, hogy hamarosan függetlenséget kapnak a Brit Koronától ${ }^{9}$. A hírt a történelem egyik legvalószínűtlenebb célját kitüzö vértelen felkelés követte, mely csak angol különleges erők bevetésével sikerült két év múlva rendezni. A gyarmati státus megmaradását követelö felkelők végül zenével, koktélokkal és brit zászlókkal várták a partraszálló brit katonákat. Azóta több példa is bebizonyította a térségben, hogy a függetlenség elnyerése káoszt, gazdasági válságot, nyomort hozhat. Mindez hozzájárul ahhoz, hogy a ma még bármilyen módon európai államokhoz kötött területeken, mint pl. a francia Guadeloupe, Martinique, vagy Francia Guyana, nem találkozhatunk komoly támogatással bíró függetlenségi törekvésekkel, mozgalmakkal, pártokkal, gerilla-, vagy terrorszervezetekkel, ami azért is furcsa, mert a francia gyarmatbirodalom, illetve általánosabban a gyarmatbirodalmak szétverésének gondolata olyan Martinique-i gondolkodóktól is eredeztethető, mint Aimé Césaire és a később Algéria függetlenségéért küzdő Frantz Fanon. ${ }^{10}$

Ugyanakkor groteszk tény, hogy a Dominikai Közösségben a Maria hurrikán 2017 öszi pusztítása után annak ellenére, hogy II. Erzsébet van minden bankjegyen és érmén, a posta és minden más hivatal falán, a Királynőhöz teljesen méltatlan állapotok uralkodtak hónapokig, nem volt ugyanis áram, élelem, lakóhely és törvény, sőt még egy ép szélvédőjü autó sem, de a Nemzetközösség nem nyújtott azonnali segítséget.

\section{Az oroszok már Alaszkában vannak}

Alaszkától San Franciscoig jöttek létre orosz telepek igen színes, ma már elképzelhetetlen képet mutatva. Oroszok, Aleut-szigeteki őslakosok, eszkimók, indiánok harmóniában éltek a föleg vidrafogásra épülő orosz településeken. Talán ennél furcsább orosz külterület csak Port Atrur volt, az orosz-japán háború előtti Kínában. Ott, akárcsak egy matrjóska babában, Kínában az orosz haditengerészeti városban volt egy kínai negyed, az úgynevezett „Kitajgorod”.

Az Orosz-Amerikai Társaság 1781-től fogta össze a már négy évtizede Alaszkában élö telepesek kereskedelmét. 1820-tól Sándor cár és a cári család is vásárolt társaság részvényeiből. Az alaszkaiak a világ

\footnotetext{
${ }^{9}$ Westlake, E. Donald: Under an English Heaven. New York, 1972.

${ }^{10}$ Békési, László i. m. 2014 
Kaleidoscope

egyik legsajátosabb pénzrendszerét hozták létre: a rozmárbőr bankjegyeken alapuló gazdaságot. Az évi több tízezer elejtett vidra kikészített börét egyben lenyúzott és így vízhatlan rozmárbőrökbe csomagolva tették hajóra. Ezt a szállítási-tárolási módot az inuitoktól tanulták. 1958 és 1980 közötti tudományos vitákban alakult át a korábbi nézet és vált elfogadottá az új, hogy ezek nem fókabőr, hanem rozmárbőr zsákok voltak. A rozmárbőr csomagokat az orosz kereskedők Alaszkából Kínába szállították. Ott az értékesített vidra bőkök árán teát és füszereket vettek, amit Oroszországba szállítottak tovább -ugyanezekben a vízhatlan rozmárbőr zsákokban. A rozmárbőrök a fuvar végén új életre keltek. A bennük szállított értékre utalva egy bankjegynyi darabot vágtak ki belölük és az Orosz-Amerikai Társaság bélyegzőjével, cári címerrel, sorszámmal és névértékkel ellátva tulajdonképpen bankjegyként kerültek vissza Alaszkába, egy olyan helyre, ahol az akkori körülmények között egy európai viszonyokra tervezett papír bankjegy sokkal gyorsabban amortizálódott volna. A rozmárbőr bankjeggyel fizettek aztán a telepeseknek, inuitoknak és indiánoknak a leadott további vidrabörökért. Hogy az írástudatlan őslakosok is meg tudják különböztetni a bankjegyek értékét, különböző méretü és formájú és kezdetben a szállított füszerektől színessé vált bőrdarabokat használtak.

Ugyanakkor a telepek nem használtak saját területükre tervezett érméket, mint más országok gyarmati lakosai. Ennek oka főleg, hogy az orosz lakosság sokkal kisebb volt más európai gyarmatosító hatalmakhoz képest. Az oroszok föleg általános orosz érmeket használtak, de leletekből kimondottan Szibériában használt orosz pénzek is előkerültek. Míg az orosz birodalom svéd és finn telepeseinek, vadászainak kereskedőinek jelenlétére az ortodox templomok mellett emelt lutheránus templomok emlékeztetnek, egy 1773 tájáról származó éremlelet arról tanúskodik, hogy az Orosz Birodalom által elfoglalt moldáv és havasalföldi területekről is érkeztek telepesek, ott használt pénzeikkel együ̈tt ${ }^{11}$. A nem dominánsan ororsz lakosságú területeken ugyanis az Orosz Birodalomban olyan sajátos érmeket használtak, ahol mind rubelben, mint a helyi szokásos pénznemben (pl finn „markkaa” és rubel, vagy zloty és rubel, vagy éppen moldáv váltópénz, a para és a kopejka) is feltüntették az értéket.

A német-osztrák vonal

Német államokból származó katonák aktívan vettek részt a brit oldalon az amerikai függetlenségi háborúban. Részvételük az amerikai eseményekben máig ható változásokat eredményezett a hadviselésben. Tulajdonképpen a német vadász (jäger) viselet nyomán kezdte felváltani a színes-tarka hadi ruházatokat (pl. a jellegzetes angol red coatot, azaz vörös zubbonyt) a zöld egyenruha. Később a Habsburg-ház is kivette részét az amerikai kontinens birodalomépítő és dinasztikus folyamataiból. A tiszavirág életü Mexikói Császárság érméin Habsburg Miksa császár (Emperador Maximiliano) szerepelt 1863-67 között.(7. ábra)

A kontinensen konkrét gyarmati területtel sosem rendelkezett, de számos németajkú várost (pl. Kanadában Berlin,-a mai Kitchener, ahová Pennsylvániából jöttek az első német mennoniták és közelében Heidelberg, Breslau stb.) benépesítö Németország is megtalálta a módját a két világháború közötti időszakban arra, hogy német érmeken, vagy érméken Amerikához kapcsolódó német tér uralási, térhódítási elemeket szerepeltessen. Ezt szintén egy (új) geopolitikai, geostratégiai uralási dimenzió ihlette. A németek folyamatosan bocsátottak ki mind forgalmi érmet (az 1929-es világot körberepülő Zeppelin expedíció alakalmából 3 és 5 márkás érmék 1930-ban) és emlékérmeket léghajók, kapitányaik és tervezőik képeivel. Ezek közül többön az észak-, vagy a dél-amerikai Zeppelin expedíciók állomásai, útvonalai és a megérkezési idők szerepelnek. Mindez egyfajta sajátos korai revans és erőfitogtatás része volt, hiszen az első világháborúban a katonai küldetéseket végrehajtó Zeppelinek még nem jutottak el az amerikai

${ }^{11}$ WWW.fortross.org

http://www.kaleidoscopehistory.hu dr.habil Békési László PhD 
Kaleidoscope

kontinens fölé, de Nagy-Britanniáig már igen (Londont is bombázták) ${ }^{12}$. Egyfajta konkrét hatótávolsággal manipuláló geostratégiai fenyegetésnek tekinthető például egy 1924-ben kiadott amerikai Zeppelin út emlékére készített érme és az érmén szereplő repülési adatsor. Ebből megtudhatjuk, hogy a léghajó egy nap alatt ért el Németországból az Azori-szigetekre, majd további egy nap alatt a kanadai partokig. Innen kevesebb, mint egy napba került Boston elérése és a Boston New York táv pedig csak három óra 29 perc volt. Ezeket a repülési rekord adatokat német precizitással percre pontosan szerepeltették az érmén, hogy mindenki értsen belölük. A légi technikai fölény e korai propagálása a kor geopolitikai-geostratégiai burkaihoz, zónáihoz, dimenzióihoz (szárazföldi és tengeri hatalmak és a haderők mozgásának egyre gyorsabbá tétele) hozzáadja a légteret, mint uralandó és szállító övezetet. (8. ábra)

7. ábra

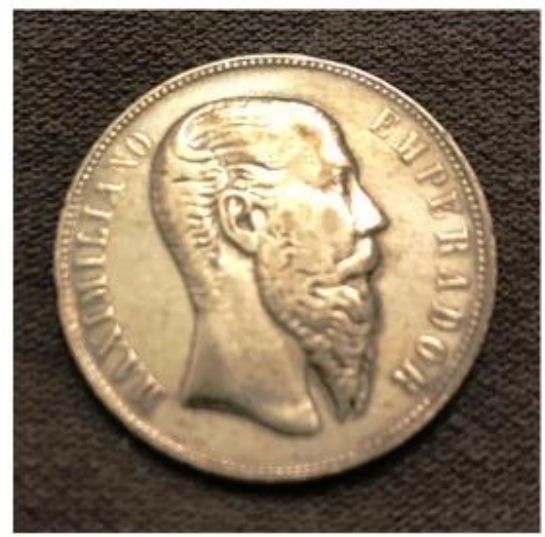

8. ábra

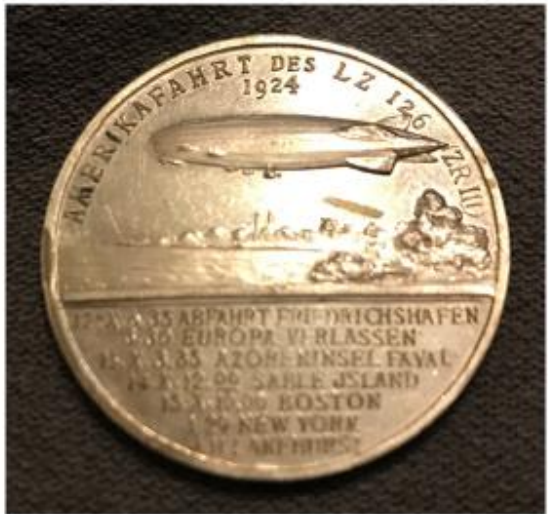

7.ábra: Mexikói Császárság, 50 Centavos, Miksa császár, 1866.

8.ábra: 1924-es Zeppelin Amerika expedíció. Emlékérem a megtett távolságokkal és menetidőkkel.

Szintén az első világháborúig a németek gyarmatbirodalmuk reputációjának emelésére más gyarmattartókhoz hasonlóan más kontinenseken is „bejelentkeztek”, azaz használtak német gyarmati pénzeket: Hong Konghoz és Makaóhoz hasonlóan egy szintén 99 évre bérbe vett Kiautschou nevü területen bocsátottak ki német-kínai feliratú érméket. Német Kelet Afrikában a Német Kelet Afrikai Társaság, majd a német állam adott ki pénzt (lépésről lépésre lemásolva a brit indiai gazdasági gazdasági-katonai terjeszkedés modelljét). A Német Új-Guineán használt német érméket pedig paradicsommadár díszítette. Az első világháború alatt talán csak a németek vertek külön megszállási érméket, méghozzá az elfoglalt belga és cári orosz területek pénzforgalmának biztosítására. Ez szintén egyfajta szimbolikus téruralás (az első világháborúban megszállt orosz területeken pl. vaskeresztet ábrázoló kopejkákat adtak ki). Egy másodlagos téruraláshoz kapcsolódó német érmehasználat Japánban már 113 éve tart: Maizuru egykori hadikikötőjének torpedóraktárában (ma tégla muzeum, hiszen ez volt Japán egyik első, és egyben német építésű téglaépülete) 1905 óta üzemel egy német wurlizter, ami kizárólag II. Vilmos császár német birodalmi pfenningjének bedobása után hajlandó zenét (német indulókat) szolgáltatni.

\section{A francia kapcsolat}

Már említettük, hogy a frankofón Québec-ben francia feliratú érmeket használtak a XIX. század végéig. Saint Pierre és Miquelon kis szigetein, a kanadai partoknál, Franciaország tengerentúli területein a mai napig

${ }^{12}$ Békési László: A politika földrajza. Budapest, 2004.

http://www.kaleidoscopehistory.hu dr.habil Békési László PhD 
Kaleidoscope Művelődés-, Tudomány- és Orvostörténeti Folyóirat Journal of History of Culture, Science and Medicine
2020. Vol. 10. No. 20.

e-ISSN: 2062-2597

DOI: $\underline{10.17107 / \mathrm{KH} .2020 .20 .308-325}$

francia a hivatalos nyelv, így a kibocsátott pénzeken használt nyelv is. Mind olyan ritka frank, mind olyan ritka euró címletekkel találkozhatnak az idelátogatók, vagy a gyüjtők, melyeket csak ezeken a szigeteken adtak ki, vagy kerültek forgalomba.

Dél felé haladva az Egyesült Államokban is találkozhattunk francia nyelvü pénzkibocsátással. Louisianában, vagyis Új Franciaországban (melynek északi területei a mai Kanada frankofón területeivel értek egybe), mindenütt francia pénzrendszer működött, mielőtt az Egyesült Államok megvásárolta. A zenei stílusra utaló Dixieland kifejezés eredetileg korábban annak a földrajzi területnek a közismert neve volt, ahol a Citizens' Bank of Louisiana tízdolláros bankjegyeket adott ki. A New Orleansban nyomtatott bankók egyik oldalán angol szöveg és névérték, másik oldalán viszont francia szöveg és névérték szerepelt még az 1860-as években is (DIX, azaz tíz, Nouvelle Orléans stb). Mindez arra utal, hogy miután a franciák eladták Louisianát, a terület még sokáig kétnyelvü volt, sőt máig kettős identitású.

A karib-térségben ma is találunk francia területeket. Ilyen Saint Barthélemy, Guadeloupe, Martinique, vagy a fél Saint Martin (másik fele a holland Sint Maarten). Sőt számos olyan sziget is van, mely csak rövid ideig került francia uralom alá, de használt francia gyarmati érméket. Mindez a földrajzi nevekben máig fennmaradt. A Dominikai Közösség vagy Saint Lucia földrajzi neveinek jelentős része több, mint két évszázaddal a francia lobogó levonása után is francia maradt. A dél-amerikai Francia Guyana is saját gyarmati pénzeket használt.

Guadelupe és Martinique a Bécsi Kongresszus után geopolitikai megközelítésben szokatlan helyzetben találta magát. A kanadai és louisianai területek már más hatalmakhoz kerültek, a francia afrikai gyarmatosítás pedig még nem kezdődött meg. Így X. Károly majd Lajos Fülöp idején mindösszesen ez a két sziget és Guyana maradt francia tengerentúli uralom alatt. A két szigeten ebben az időben olyan francia érméket használtak, amin nem jelölték meg a forgalomba bocsátás helyét. Egyszerüen azt a köriratot tartalmazták az érmék, hogy „Francia Gyarmatok”, hiszen a gyarmatok mindössze ezt a pici területet jelentették. Tehát a földrajzi hely megjelölése nélkül is utaltak a földrajzi helyre. (9. ábra)

A helyi ellentmondásos viszonyokat legjobban tükröző érme is minden bizonnyal Martinique-hoz kapcsolódik. Itt 1897-ben, majd 1922-ben bocsátottak ki olyan forgalmi érmeket, melyek csak ezen a szigeten voltak használatban. A pénzek egyik oldalán a névérték a másik oldalon a Republique Francaise Colonie de la Martinique felirat és egy női fej látható. A hölgy nem más, mint Napóleon felesége, Josephine, aki Martinique-i rabszolgatartó, cukornád termesztö, ültetvényes családban született és nevelkedett, s így a sziget leghíresebb szülöttje volt akkoriban (azóta talán Aimé Césaire és Frantz Fanon a leghíresebb Martinique-iek). Josephine megítélése a szigeten mindig is egyértelmű volt: Josephine „érdeme” az volt, hogy a francia forradalom alatt eltörölt rabszolgaság intézményének visszaállításáért lobbizott „sikeresen” Napóleonnál, saját családja érdekeit szolgálva. Mivel a szigeten ma is 97-98\%-ban egykori rabszolgák leszármazottai élnek, a III. Napóleon által intézményesített Josephine-kultuszt a helyiek nem tudták soha elfogadni. A gyülölt császárnőnek III. Napóleon szobrot is állíttatott Fort de France-ban, a sziget fóvárosában. A szobor ma is áll, a helyiek azonban leverték a fejék (a szobor szimbolikus guillotine-os kivégzése), nevét pedig kivésték a talapzatról. A fejetlen, olvashatatlan feliratú, festékkel összedobált szobor-torzó helyreállítását a helyi hatóságok nem merik megkockáztatni az 1991-es rongálás óta, hiszen a restaurálási kísérlet valószínúleg véres felkelésbe torkollna.

http://www.kaleidoscopehistory.hu dr.habil Békési László PhD 
Kaleidoscope

9. ábra

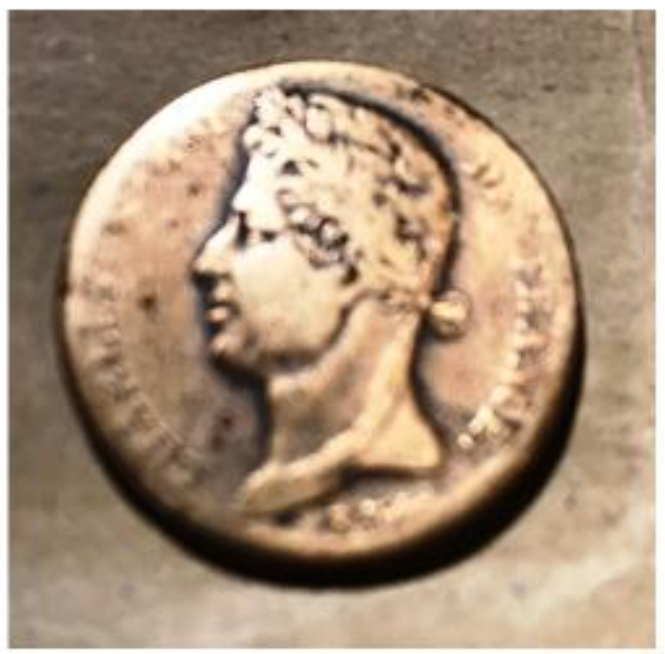

10. ábra

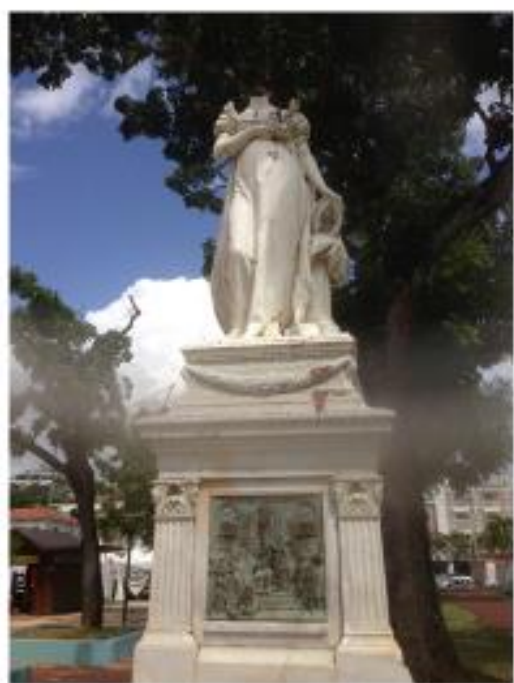

9. ábra. X. Károly 5 Centimes érméje hátulján földrajzi hely megjelölése nélkül is egyértelmüen Martinique és Guadelupe szigetére utaló felirattal: Francia Gyarmatok 1827.

10.ábra: Josephine (leguillotine-ozott) fejü szobra a Martinique-i Fort-de-France belvárosában.

A szobor követi ma is az aktuális eseményeket. Nemrég sárga mellényt kapott a franciaországi tüntetéssorozattal szimpatizálóktól.

Ugyanezt a történetet egy fellelt érmén is nyomon követhetjük (az említett mikrokutatás módszere, amivel helyi hatalmi viszonyokat fejthetünk meg). 2013-ban sikerült a Martinique-i Saint-Pierre település egyik romos templomának közelében egy ilyen Josephine-t ábrázoló érmét találni. Az érme, maga az érme állapota és a helyszín az egész történet megfejtését hordozta magában. Az érmét pontosan Josephine fejénél átütötték, kilukasztották egy pontozóval, vagy szöggel. Ezután az érmét, mint egy üzenetet, a templom perselyébe dobhatta megrongálója. A perselyt felnyitó egyházi személy pedig a meggyalázott, értéktelenné tett érmét egyszerüen behajította a templom udvarán a bokrok közé. Mindez 1897 és 1902 között történhetett, ugyanis maga az érme 1897-es, de 1902-ben egy piroklasztikus, forró gázt kilövellő vulkánkitörés megsemmisítette a települést és összes, közel 20000 lakosát $^{13}$. Gondoljuk el, hogy ekkoriban még az ötvenes éveikben lévő, vagy még idősebb szigetlakók mind-mind rabszolgaként látták meg a napvilágot és személyes tapasztalatuk nagyon is élő volt minden család számára. A rabszolgaságot csupán 1848-ban törölték el véglegesen, tehát az egykori rabszolgáknak és gyermekeiknek egy olyan érmét kellett nap, mint nap használniuk, amin az a személy volt, aki visszaállíttatta a rabszolgaságot. Az is lehet, hogy a Josephine képmásával díszített érméket tömegesen „fejezték le”, lukasztották át így a szigetlakók az előző századfordulón, azonban ezidáig csupán ez az egyetlen lelet került elő.(11.ábra)

Vérfagyasztó színjáték volt Martinique-on a második világháború eleje is, amikor a színesbőrűek által lakott francia sziget a nácibarát Vichy kormány fennhatósága alá került. Franz Fanon a szomszédos, akkor még

\footnotetext{
${ }^{13}$ Sérafini, Dominique-Imbert, Jacques-Yves-Sardi, Patrick: Saint-Pierre L'Escale Infernale. Saint-Pierre, 2015. http://www.kaleidoscopehistory.hu dr.habil Békési László PhD
} 
Kaleidoscope

brit Dominica szigetére szökött és csatlakozott a fasizmus elleni harchoz. Viszont a háború vége felé kimutatta, hogy maga a szabad franciák állama is hasonlóan rasszista, dehumanizáló, hiszen egy újság haditudósításának fotóján az akkor éppen francia önkéntesként a nácik ellen Európában harcoló színesbőrü Martinique-i Fanon arcbőrét fehérre retusálták ${ }^{14}$. Hogy megérthessük a helyzete, segítségül kell hívnunk a térség francia bélyegeit a második világháború alatt. A szigetvilágban még a bélyegek és a bankjegyek is harcra keltek egymással. Utópia és Ukrónia volt ez a párhuzamos valóság. Egyszerre szinte megegyező tematikájú jelképrendszerrel operáltak a Vicy által kinevezett antillai Robert Admirális Főbiztos és De Gaulle hívei. Az igazolható, hogy a földgömböt és a világtérképet egyszerre néző álmodozó fehér fiú egy fasiszta bélyegen jelenik meg. De ugyanebbe a fasiszta sorozatba tartozik a színes csecsemőt cumiztató fehér nővért és az anyját ellátó fehér ápolónőt ábrázoló bélyeg. Fasiszta a Pétain fej Martinique-i tengerparti tájjal és a „Birodalom védői” sorozat, ahol a gyarmati gyalogos, a tengerészgyalogos lövész és a gyarmati géppuskások szerepelnek. Ugyanezek a katonák és tengerészek ugyanakkor ugyanezekben az egyenruhákban De Gaulle oldalán is harcoltak, ugyanezekkel a francia fegyverekkel. De ugyanakkor a Londonban legyártott rabszolgafelszabadító Schoelcher, fríz sapkás női fej és Félix Éboué, Csád fekete kormányzója, aki egész Afrikát De Gaulle irányába fordította, de Guyanáról származott, vagy a Kettős keresztes repülő már a Szabad Franciák postaszolgálatának leveleit díszítette. A tudomány az „Egzotikus gyümölcsök" bélyegsorozatnál áll meg egy pillanatra. A sorozatot mindkét oldal használta. A fasiszták a Francia Köztársaság RF monogramja helyére is névértéket nyomtattak 1943-ban, míg a Szabad Franciák ugyanazokkal a gyümölcsökkel postálkodtak de RF rövidítéssel, ez még az 1938-ban kiadott eredeti sorozat volt. Természetesen mindkét oldal használta a Martinique feliratot és frankban tüntették fel a névértéket. Hol fasiszta, hogy szabad frankkan fizettek... De mielőtt a pénzekre visszatérnénk, meg kell említeni, hogy ez a bifurkáció teljesen ugyanilyen szakadásokat eredményezett a többi szigeten. Ugyanezen bélyegeket megtaláljuk a szabad és németbarát Francia Guyanán (plusz egy gyarmati csendőrös bélyeg), Guadelupeon Guadelupe felirattal (plusz egy romantikus bélyeg ahol cukornádat dolgoznak fel, amit 1928-ban terveztek de annyira megtetszett a németbarát kormányzatnak, hogy 1940-től újra kiadták). Majd a cukornád téma annyira megtetszett a fasisztákat legyőző Gaullistáknak, hogy 1947-től nosztalgikus hangulatot idéző fekete kávészedőket, cukornádvágókat és ananászszedőket is ábrázoltak bélyegen. Ugyanígy a fasizmus legyőzése után szintén 1947-ben Guyanán kiadtak egy légiposta bélyeget két sassal, akit teljesen a fasiszta szimbolika sas ábrázolásaira emlékeztetnek. ${ }^{15}$ A Martinique-i kaotikus második világháborús helyzetre jellemzö volt, hogy gyakorlatilag egyszerre volt forgalomban a Vichy kormány helyben nyomtatott bankjegysorozata (aminek összes darabján egyetlen képi elem volt, Pétain marsallbotja), egy Amerikában, Philadelphiában nyomtatott dollárhoz hasonló képi világú bankósorozat (mind a fasiszta, mind az amerikai Banque de la Martinique felirattal), továbbá egy amerikai tulajdonú angol pénzjegynyomda bankjegysorozata, amin viszont a Francia Tengerentúli Pénztár felirat volt olvasható ${ }^{16}$. Az érmékek a kavalkádhoz a Vichy kormány szolgáltatta, ahol a szabadság-egyenlöség-testvériség jelszavát a fasiszta franciák munka-család-haza jelszava helyettesítette. Az említett Bradbury and Wilkinson angol pénzjegynyomda számos ország (Mexikó, Románia, stb.) bélyegeit és bankjegyeit tervezte és gyártotta le a XIX-XX-ik században. Leghíresebb azonban minden bizonnyal az 1968-as Seychelle-szigeteken használt rúpia bankjegysorozatuk lett amin a szexuális forradalom csúcsán a lelkes tervező a 50 rúpiásra II. Erzsébet királyné mögé úgy rendezte a pálmafákat, hogy a lomborona a SEX feliratot formázza. A 10 rúpiáson a királyné felé egy vidám teknőc úszik, aminek hátsó lábainál a korall SCUM (sperimum) szót adja ki.

\footnotetext{
${ }^{14}$ Fanon, Frantz: Black Skin, White Masks. New York, 1967,

${ }^{15}$ Puiboube, Christian: Les Antilles et la Guyane á travers leurs timbres-poste. Fort-de-France, Martinique. 2016

${ }^{16}$ Musée Départmental d'Archéologie Précolombienne et de Préhistoire: Echanges et Monnaies á la Martinique des Amérindiens ... á l'Euro. Fort-de-France, Martinique 2001. 
Kaleidoscope

Ma az euró a hivatalos fizetőeszköz a francia karibi tengerentúli megyékben. Ezen szigetek térképe (akárcsak a szintén eurót használó Francia Guyana sziluettje) külön szerepel minden forgalomban lévő euró bankjegy térképet ábrázoló oldalának bal alsó sarkában. A helyi párás viszonyokkal magyarázható egy furcsa jelenség is: a karib-térségben olyan nagy a páratartalom, hogy az új, nyilvánvalóan európai viszonyokra gyártott euró cent érmék akár néhány óra alatt rozsdásodásnak indulhatnak, ha a talajra esnek (azaz az Európai Unió nem globális impériumépítésre berendezkedett szervezet, nem számoltak azzal, hogy az Euró pénzrendszer Európán kívül is terjedni fog). Ugyanakkor a korábbi földre esett angol, spanyol és francia gyarmatokon használt érmék -akár III. Napóleon korából, vagy a korábban említett X, Károly idejéből is- tökéletesen bírták a páratartalmat és sértetlenül kerülnek elő ugyanitt (azaz készítőik már akkor számoltak a világ különböző területein történő használattal, impériumaik szélsőséges éghajlatú területeivel).

11. ábra

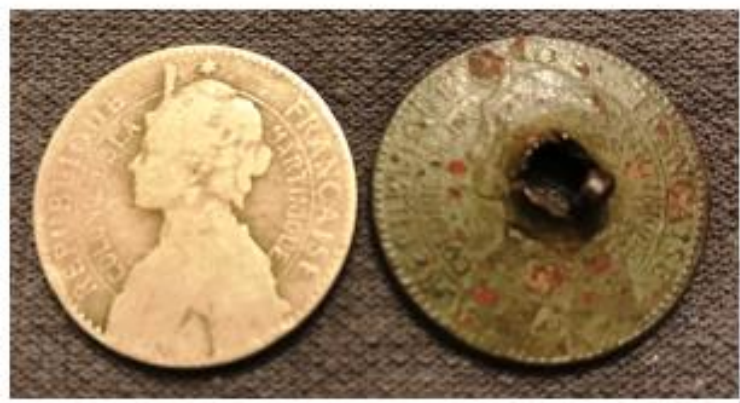

12. ábra

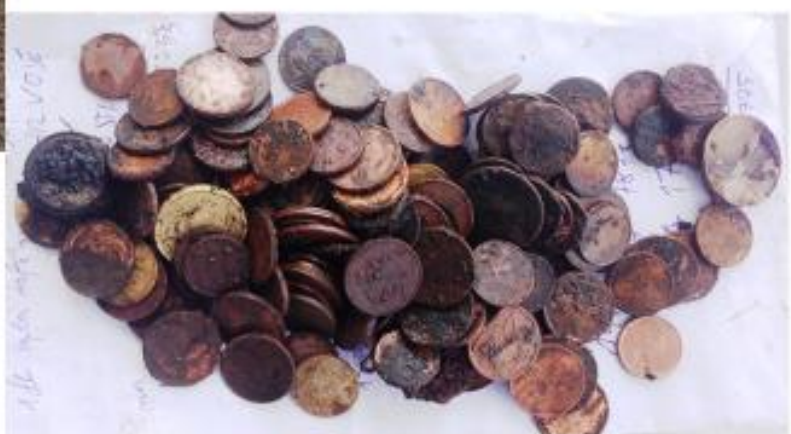

11.ábra: sértetlen és „lefejezett”, tisztítatlan Josephine-t ábrázoló Martinique-i gyarmati forgalmi 1 franc 1897-ből. 12.ábra: Egy karibi néhány órás mikrokutatás eredményei. 2012.

Azonban más francia tengerentúli területeken nem vezették be az eurót, Francia Polinéziában például ma is Csendes-Óceáni Frankot használnak.

\section{Szóba se jöhet Skandinávia?}

A viking korban talán az első európaiként a skandináv törzsek hajósai érték el az amerikai kontinenst. Az azonban kevésbé ismert, hogy mind a svédeknek, mind a dánoknak voltak a Karib-szigetvilághoz köthetö területei a modern időkben is. A svédek Szent Bertalan szigetét birtokolták. Saját pénzeket nem adtak ki, a környező szigetek pénzeit használták, esetleg ellenjeggyel, azaz valamilyen hitelesítő, ellenőrző beütést tettek az érmékre.

A dánok is használtak saját ellenjeggyel ellátott Egyesült Államokból származó fémpénzeket, azonban már a XVIII. századtól Dán Amerika, (13. ábra)majd Dán Nyugat-India feliratú Koppenhágában vert érméket is használtak birtokaikon (a mai Amerikai Virgin-szigeteken). (14. ábra)A széles repertoárba még kókuszpálmás dán szecessziós jegyeket mutató aranypénzek kibocsátása is belefért a XX. század elején. Az itt használt dán váltópénz a cent és ötödrésze, a bit volt, de használtak skillinget, frankot és dalert is (a tallér 
Kaleidoscope

dán megfelelője, de nem véletlen, hogy angolul dollárnak fordítják). Azaz a dánok már a XIX. században kiadtak bit coint. A dán területeket 1917-ben eladták az Egyesült Államoknak ${ }^{17}$ ezzel a skandináv amerikaikaribi impérium-fenntartás véget ért. Az amerikaiak azonban még 1917 után is, egy átmeneti ideig megtartották a helyi dán pénzrendszert.

\section{3. ábra}

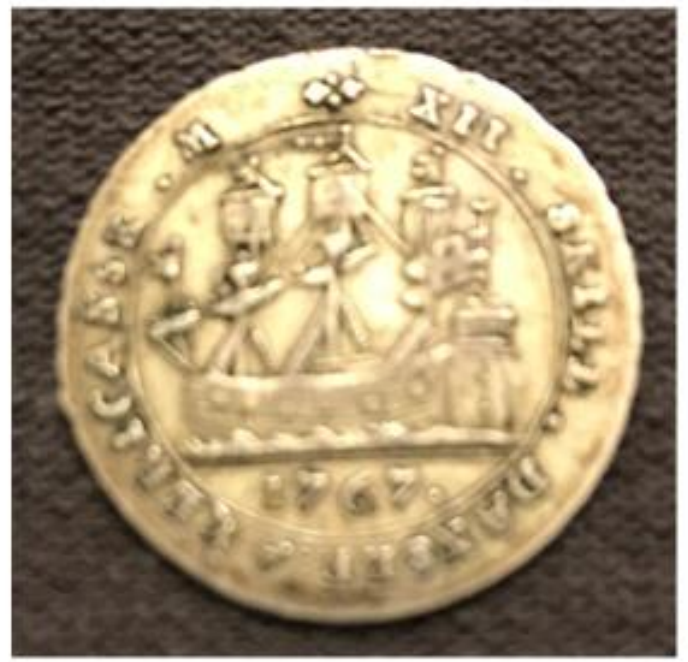

14. ábra

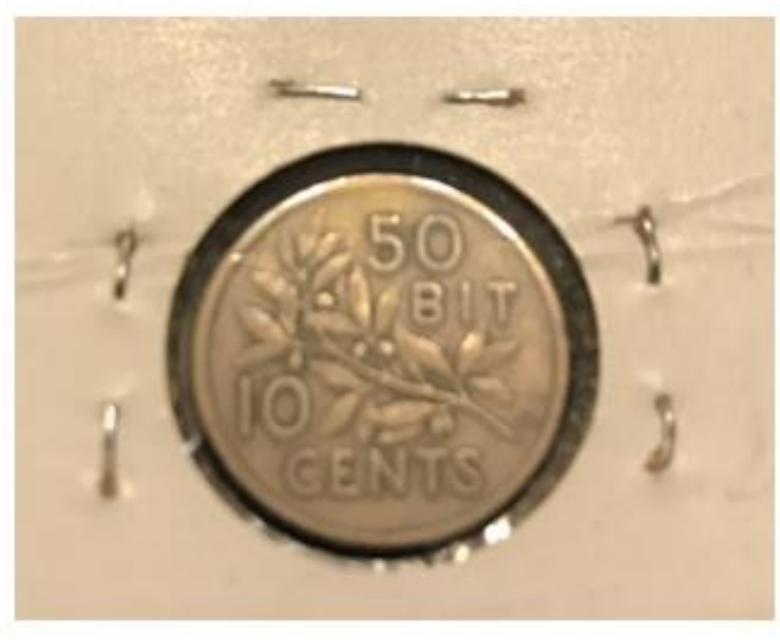

13.ábra: XII. Skilling háromárbócos vitorlás ábrájával és VII. Christian Dán-Norvég király monogramjával. Dán Amerika, 1767. 14.ábra: 10 cent, azaz 50 bit, Dán Nyugat-India, 1905.

A gyarmatokon a szűkös lehetőségek miatt, esetleg blokádok idején, amikor az anyaországból nem jöhetett sem forgalmi pénz sem árucikk, sem élelem az egész világon előfordult, hogy más közeli hatalmak érméit használták akár természetes állapotukban, akár ellenjegyet ütve rájuk, akár feldarabolva, vagy kilukasztva a tényleges nemesfémtartalom értékén számolva az érméket. Az anyaországtól elvágott Német Kelet Afrikában Tabora város vagonjavító mühelyében az első világháború alatt a helyi hatóságok háromszázezer 20 helleres váltópénzt gyártottak le 1916-ban a legprimitívebb körülmények között. A XIX. századi dán gyarmati pénzeket viszont igen szép kivitelben és nemesfémböl folyamatosan helyben készültek. Erre utal a X. és XX. Skillinges érméken a felirat: Dán-Ameikai Pénzverde. De a hollandok is vertek helyben guldeneket.

\section{A holland területek}

A Holland-Antillák történetükben akkor váltak kiemelten fontossá, perifériából centrummá, mikor a németek megszállták Hollandiát, a japánok pedig megkaparintották Holland Kelet-Indiát, a mai Indonéziát (ahol a helyzet bonyolítására japán guldent vezettek be holland felirattal) a második világháborúban. A kormány és a királyi család Londonba menekült, bár az otthon maradt lakosság egy része kimondottan együttmüködött a németekkel. Ettől kezdve a holland állam -akárcsak a korabeli francia- megkettőződött. Ennek a furcsa bifurkációnak a pénzkibocsátásban is megvoltak a következményei. A német uralom alatt a hollandok holland guldent és centet használtak alakjukban, méretükben és formájukban a korábbiakkal

\footnotetext{
${ }^{17}$ Hanna, Nick-Stanford, Emma: Karib-térség. Budapest, 2009. 
megegyezőt (pl. az ötcentes lekerekített sarkú négyzet alakú volt). A királynő fejét azonban kereszttel, tulipánnal, hajóval helyettesítették a holland nemzetiszocialista éremmüvészek. A bifurkáció másik ágát a hagyományos, emigrációhoz kapcsolható érmek jelentették. Akárcsak a hagyományos holland sisakok, ezek az érmék is az Egyesült Államokban készültek tovább San Francisco, Denver és Philadelphia pénzverdéiben, vagy éppen a Holland Antillák Curacao-i, vagy a Suriname-i pénzverdéiben. Ezek az érmek viszont a megszállás elötti érmek hagyományát folytatták ugyanazzal az uralkodót, Wilhelminát ábrázoló éremképpel. Tehát a német megszállás alatt pl. Hollandiában és az emigráns kormányhoz, vagyis a szövetségesekhez tartozó Antillákon is ugyanolyan négyszögletes ötcentesek voltak forgalomban. Csak az egyik helyen egy új náci szimbolikával, a másikon az 1940 előtti hagyományokat, pontosan az 1913 és 1940 közti éremképet 100\%-ban másolva készültek a hasonló alakú, méretü és névértékü pénzek. Az emigráns kormány által kibocsátott érméket a surinami (holland guyana-i), a Curacao-i és az említett Egyesült Államokbeli pénzverdében készítették ${ }^{18}$. Azaz ameddig 1940 előtt és 1945 után a Hollandiában és a Holland-Antillákon használt érmek egymástól eltértek (alá-fölé rendelt gyarmati viszony), addig 1940 és 1945 között maguk a holland gyarmati pénzek viselték a korábbi otthoni pénzek jegyeit és biztosították szimbólumaikkal és a királynő képmásával az állam folyamatosságát (egyenrangú, vagy önazonos viszony).(15, 16, 17. ábra)

\section{5. ábra}

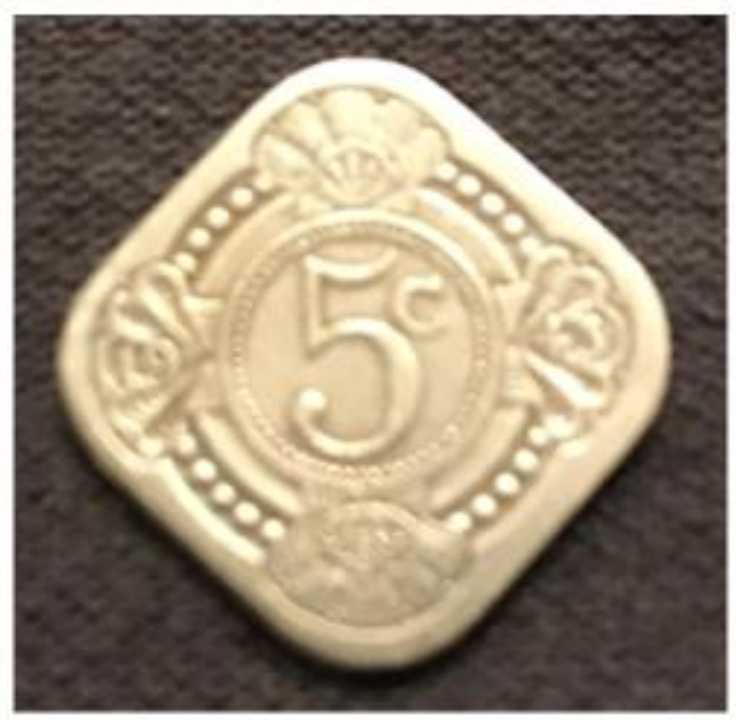

\section{6. ábra}

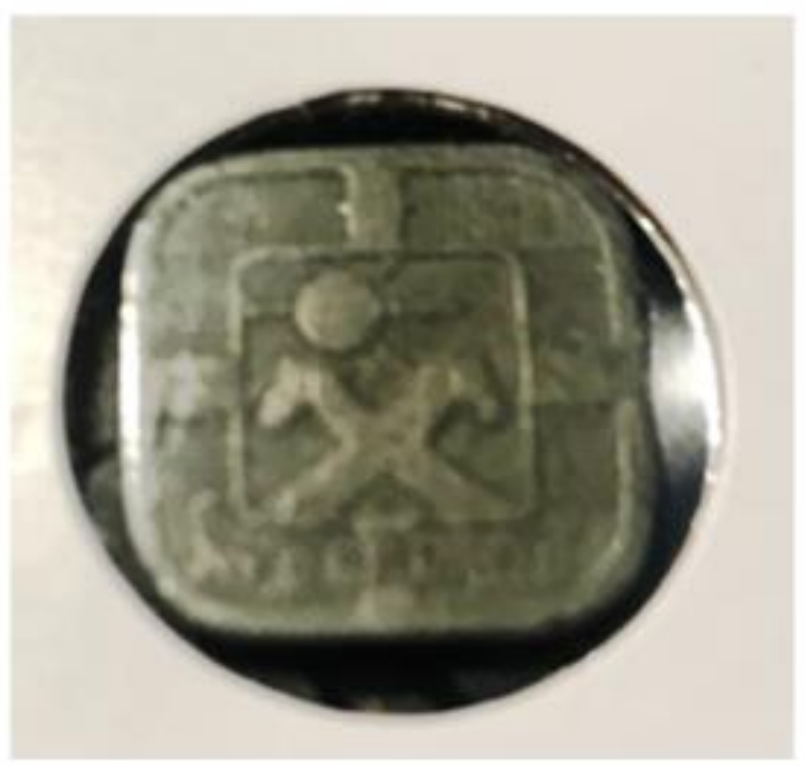

${ }^{18}$ Schön, Günter: Weltmünzkatalog. i. m. 


\section{7. ábra}

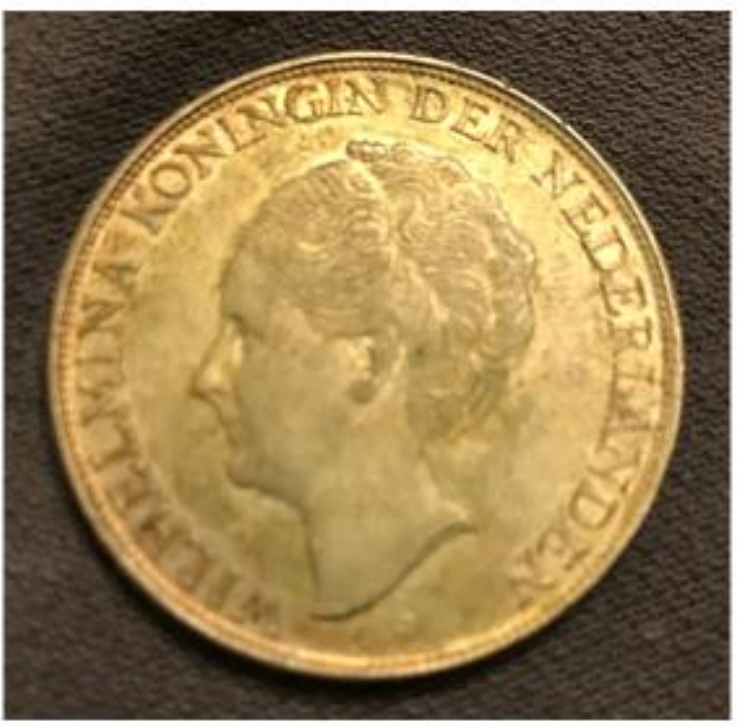

18. ábra

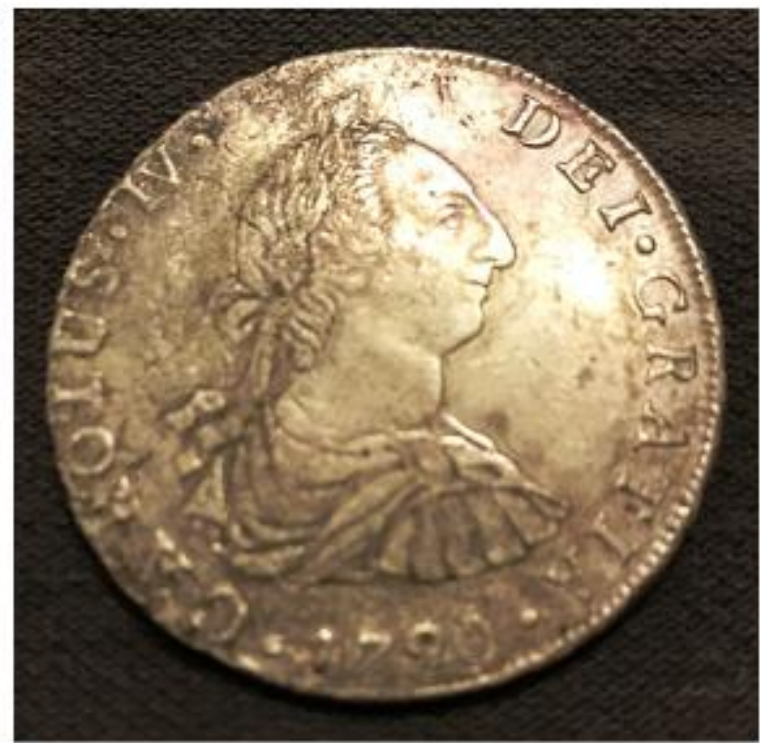

15.ábra: Holland négyzet alakú gyarmati 5 centes, 1943. A kör formától eltérő, szögletes, vagy hullámos szélü érrmék megalkotásának egyik konkrét gyakorlati oka, hogy az ilyen érmék nem gurulnak sehová a leesés helyéről. Míg a négyzet, vagy sokszög alakú érmék viszonylag elterjedtek, háromszög alakú érmét csak a Cook-szigeteken készítettek. 16.ábra: Holland 5 centes a német megszállás alatti anyaországból, szintén négyzet formával 1941.

17.ábra: Wilhelmina 2,5 gulden, Curacao-i gyarmati pénzverde, 1944. Az éremkép teljesen megegyezik az európai holland 1940 előtti formatervezéssel.

18. ábra: Potosíban vert spanyol 8 reál 1790. Semmiben nem tér el a spanyolországi, mexikói, fülöp-szigeteki, vagy más gyarmati veretektől

Gondoljuk át az érdekes bifurkációt a két hollad második világháborús példán:

A hollandok a románok számára is gyártottak holland sisakot 1940 előtt. Majd a németek a megszállt hollandia összes megmaradt sajátos alakú sisakját átadták román szövetségeseiknek. Ugyanakkor a holland gyarmari csapatokat az Egyesült Államokban gyártatott holland sisakokkal látták el a nemzeti identitás és a kontinuitás megtartása érdekében. Tehát egymással szembenálló oldalon ugyanazok a holland nemzeti sisakok harcoltak. És ugyanígy mind a németek által megszállt és részben kollaboráns Hollandiában, mind a szövetségesek segédcsapataiként végső soron Hollandia felszabadításán serénykedő gyarmatokon ugyanazt a formájú, régi szép időket idézö ötcentes használták.

Suriname 1975-ben nyerte el függetlenségét, mégis 2004-ig guldennek hívták a fizetőeszközüket, ekkor tértek át a Suriname-i dollár pénzegységre.

\section{Spanyol érmek}

A kontinens egyik legelső gyarmatosító hatalma a kezdetekben a többi gyarmattartó birodalomhoz képest fordított pénzkibocsátást valósított meg. A legtöbb amerikai területtel rendelkező európai hatalom ugyanis olyan érmeket használt, melyeket európai pénzverdékben állítottak elö, ugyanott, ahol saját belföldi forgalmi érméiket is készítették. Ezek alapanyagát is Európában bányászták. Az európai és a gyarmatokra szánt pénzek azonban eltértek, pl. szerepelt rajtuk azon gyarmat neve, ahol fizetőeszközzé váltak. A spanyolok ellenben magát a pénz alapanyagát, az ezüstöt is az amerikai kontinensről szerezték be, http://www.kaleidoscopehistory.hu dr.habil Békési László PhD 
Kaleidoscope

elöfordult, hogy az Európába tartó hajókon verték a pénzt (un, hajós tallér), ami aztán az európai Spanyolországban került forgalomba. A nagy mennyiségü ezüst Európába áramlásával felborították Európaszerte az arany és az ezüst ár arányát. ${ }^{19}$ A gyarmatokon használt pénzeiken sem szerepeltek a területek nevei, hanem egységesen az uralkodó képe és a felirat, hogy az adott uralkodó isten kegyelméből Hispánia királya. Azonban ezeket a pénzeket sem Európában verték, hanem a helyi latin-amerikai nemesfémlelöhelyek, leginkább ezüstbányák közelében, így föleg a kevésbé képzett helyi vésnök által kifaragott primitívebb éremképe alapján lehet beazonosítani a gyarmati kiadású vereteket. (A Római Birodalomban ugyanígy lehet megkülönböztetni a Rómában, vagy a provinciákban készült érméket és egyéb tárgyakat). Az egyik leghíresebb ezüstpénzt verő spanyol gyarmati város a mai Bolívia területén épített Villa de Imperial Potosí volt, melynek bányájából a kor legnagyobb mennyiségü ezüstje árasztotta el a világot a XVI. század közepétől(18. ábra).

A pénzegységek nevei sem mutattak eltérést, pl. ugyanabban az időben a birodalom minden részén reálban mérték az árakat, vagy előfordult, hogy a pénz súlya volt a tényleges vásárlóértéke, nem csak nemesfémek, hanem pl. rézpénzek esetében is. Tehát a spanyol uralkodók kifejezetten az egységes impérium képének kialakítására törekedtek békeidőben éppúgy, mint háborúk idején. Ellenben a már említett és az egész világot behálózó angol gyarmatbirodalomban igen színes és változatos pénzegységekkel találkozhattunk, például font és dollár, penny és cent, továbbá a nem decimális rendszerből adódó egyéb egységek, mint farthing, guinea, schilling, crown, vagy helyi hagyományokat követő anna, rúpia, cash (a Brit Kelet Indiai Társaság korai pénzegysége) is jelen voltak.

\section{A portugál világbirodalom numizmatikai lenyomata}

Terjedelmi korlátok miatt a portugál pénzverés gyarmati történetéből egyetlen furcsa momentumot emelnék ki. 1807-ben Napóleon hadai elindultak a portugál föváros felé. A katonákat elfelejtették értesíteni, hogy Lisszabonban ünnepi pompával várják a sereget, ezért útközben mindent feldúltak. A megrémült portugál királyi család ezért az egész udvart, tizenötezer embert és minden intézményt Rio de Janeiroba evakuált az angol flotta oltalma alatt. Rio maradt a portugál állam fövárosa egészen 1820-ig, amikor János király visszaköltözhetett az elcsendesült Európába. Az átmeneti időszakban a brazil területek annyira felfejlődtek, hogy a királyi család távozása után nemsokkal el is szakadtak az anyaországtól. A Rióba költöztetett intézmények között volt a teljes levéltár és természetesen a pénzverde is. Így Rióban verték a portugál pénzeket, köztük a crusado-t. Nevét az ezüstpénzen látható keresztről kapta. Tehát semmilyen különbség nem volt a gyarmati és a korábbi, vagy a későbbi európai portugál érmék között, sőt a kibocsátás helyét is csak az évszám és az evakuálás ismeretében tudjuk beazonosítani. A crusado valószínüleg matematikailag a legérdekesebb pénzek közé tartozik. 1688-ban 20\%-kal felment az ezüst ára Portugáliában. Addig egy crusado 400 reist ért és így a 400-as szám szerepelt az érmén is. Az áremelkedéstől kezdve viszont már 480 reist ért ugyanaz az ezüstpénz. Mivel nem szerettek volna keveredést és igen költséges lett volna bevonni és újra, új 480-as számmal újraverni a hatalmas mennyiségü forgalomban lévő ezüst crusado-t, úgy döntöttek, hogy az árváltozás ellenére 400-as névértékkel látják el az újonnan kiadott érméket is és így a régiek is forgalomban maradhatnak egy átmeneti ideig. Végül ez az átmeneti idő pontosan 150 év lett, ugyanis 1688-tól 1838-ig gyártották tovább a 480 reist érő ezüstpénzeket a rajtuk szereplö 400-as számmal. Tehát a brazíliai gyarmaton mind korábbi, mind a későbbi az európaiakkal teljesen megegyező kinézetü pénzek voltak forgalomban egészen a függetlenség kikiáltásáig. Sőt a brazil gyarmat önállósága felé tett egyik lépésként elérte, hogy a Portugál Birodalmat 1815-től rövid ideig Portugál-Brazil-Algarvei

\footnotetext{
${ }^{19}$ Békési László: Ferdinánd-kori pénzverés a Királyi Magyarországon OKTV Dolgozat, Kézirat Dunakeszi, 1986. http://www.kaleidoscopehistory.hu dr.habil Békési László PhD
} 
Kaleidoscope Müvelődés-, Tudomány- és Orvostörténeti Folyóirat

2020. Vol. 10. No. 20.

e-ISSN: 2062-2597

Journal of History of Culture, Science and Medicine

DOI: $\underline{10.17107 / K H .2020 .20 .308-325}$

(Algráviai) Egyesült Királyságnak hívták, azaz alárendelt szereplőből egyenlő féllé vált a gyarmat, mindezt az új államnevet a crusado-n is szerepeltették(19. 20. ábra).

19. ábra

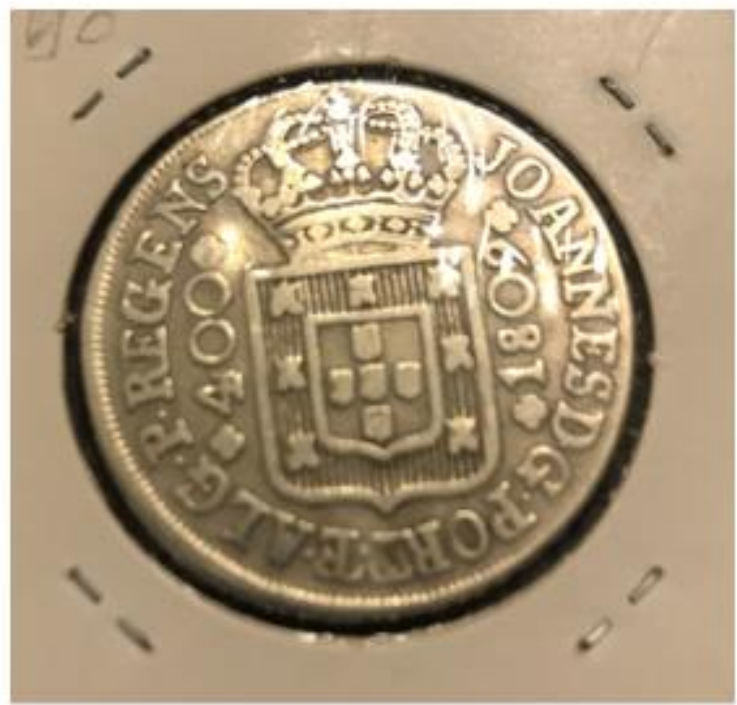

20. ábra

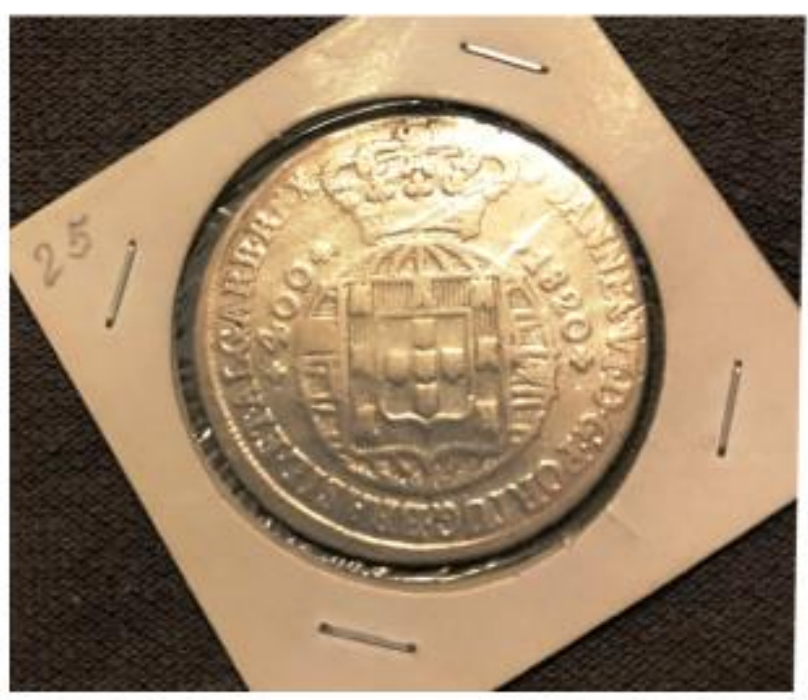

19.ábra: Portugál (1809) Crusado a Riói pénzverdéből.

20.ábra: Portugál-Brazil-Algarvei Egyesült Királyság (1820) Crusado, immár Európából. Mindkettő 400 reis felirattal, de 480 reis értékkel.

Egy mai európai hatás is megfigyelhető a brazil érméken. A mai brazil érmek formájukban, betűtípusukban, anyagaikban az euró váltópénzeinek dizájnját követik. Például az 1 real ugyanolyan bimetál (kétféle színü, belül fehér, kívül sárga), az 1-es számjegy ugyanúgy dől, mint az európai egy eurós, vagy eurócentes érméken.

21. ábra

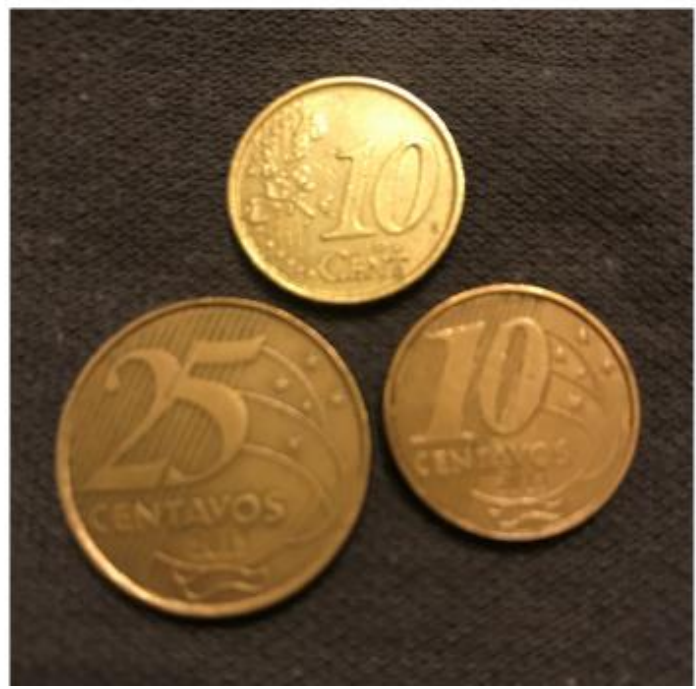

21.ábra: eurócent és brazil centavosok, megegyező design.

http://www.kaleidoscopehistory.hu dr.habil Békési László PhD 
Kaleidoscope

A portugálok -a spanyolokhoz hasonlóan világbirodalmuk teljes összeomlásáig a homogén birodalom és homogén pénzügyi rendszer képét örizték. Mind Timoron, mind a Zöldfoki-szigeteken, mind Sao Tomé e Principén, mind Mozambikban, mind Guineában, mind Angolában, ezen területek megnevezésén kívül teljesen egyforma tervezésü, nemesfém tartalmú, méretü érméket bocsátottak ki escudo pénznemben. Az indiai területeiken 1958-ban tértek át a rupiáról szintén az escudora. Egyedül Makaón számoltak és számolnak ma is patacasban. Érdekesség és a birodalomépítések és a korai globalizáció furcsaságát mutatja a következő néhány tény: Timoron is patacast használtak a portugálok, azonban a második világháború alatt ezt a teületet is megszállták a japánok, (pedig a porugálok nem álltak hadban), és a japánok a holland keletindiai gundent vezették be, Timoron ugyanúgy, mint ahogy meghagyták Holland Kelet-Indiában is, de Japán Guldennek nevezték át. Mind a makaói, mind a timori patacast úgy alkották meg 1894-ben, hogy pontosan egy mexikói ezüst pesót értek, mivel mindkét helyen mexikói pesóban számoltak korábban.

\section{Záró következtetések}

A forgalmi pénzeket, érméket vizsgálva a nemzetközi kapcsolatok szemszögéböl, érdekes geostratégiai és geopolitikai gondolatokat fogalmazhatunk meg. Az érmék elsősorban, elsődleges jelentésüket (denotáció) tekintve fizetőeszközök és felhalmozott tőkék részei, vagy éppen értékmérők, csereeszközök voltak. Másodlagos jelentésükben (konnotáció) azonban egy állam országimázsának, hatalmi jelenlétének tudatosan manipuláló szimbolikával ellátott, térkijelölő kellékei. A legtöbb európai hajózó hatalom nyugalmi állapotban éremkibocsátásában ténylegesen alárendelt gyarmatként kezelte amerikai és karibi területeit, azaz eltérő pénzeket, pénzrendszereket használt az anyaország és a gyarmat. A gyarmatokon gyakran konkrétan a gyarmat szót is szerepeltették az érmeken, bankjegyeket de a bélyegeken is. Válságok, háborúk esetén azonban az egység, összetartozás vált a legfontosabb tényezővé, így az érmek szimbolikája, üzenete is megváltozott. Szorongatott helyzetekben az egységes állam ideálját mutatták be az érmék, egyenrangú gyarmati területek illúziójával. A portugál történelem Napóleon-kori és a holland történelem második világháborús vészes korszakában az amerikai/karibi területek müködtek a tényleges államként, biztosítva az anyaország kontinuitását, jogfolytonosságát, igazolva az igényt az európai területeik visszaszerzésére. Ilyenkor a hajdani európai pénzeikkel teljesen megegyező, azonban a gyarmatokon használt érméket bocsátottak ki. Mindez a nemzeti szimbólumok és a tér uralásának folyamatosságát biztostó komplex és tudatos szimbólumrendszer része volt. Az emigrációba kényszerült holland kormány például a második világháború alatt az állami kontinuitás szimbólumaként nemcsak holland pénzeket használt az Antillákon, hanem Millwaukee-ban gyártatott költséges és elavult, régimódi holland formájú acélsisakkal is ellátták az itt ragadt katonáikat, hogy megtartsák a holland hazafias érzelmeket ${ }^{20}$.

Bifurkáció zajlott le holland és francia területeken a második világháborúban:

A hollandok furcsa sisakjai egy ellenséges hatalomhoz kerültek és ott is nemzeti szimbólummá váltak (sőt Ceaucescu Romániája is a régi holland sisak formáját használta). Ugyanakkor a holland gyarmati csapatokat az Egyesült Államokban újonnan gyártatott holland sisakokkal látták el a nemzeti identitás és a kontinuitás megtartása érdekében. Tehát egymással szembenálló oldalon ugyanazok a holland nemzeti sisakok harcoltak. És ugyanígy mind a németek által megszállt Hollandiában, mind a szövetségesek oldalán harcoló megmaradt gyarmatokon ugyanazt a formájú, 1940 előtti időket idéző ötcentes használták.

Franciaország is megkettőződött a második világháború alatt, de a Vichy-kormány hazai éremkibocsátását ellensúlyozandó a szabad francia területeken nem az 1939 előtti pénzekhez tértek vissza, hanem új formatervezésekkel kísérleteztek.

\footnotetext{
${ }^{20}$ Békési László: Mutasd a sisakod, megmondom ki(vel) vagy! Szakmai Szemle . 11. évf. (2014). 3. sz. 46-54 http://www.kaleidoscopehistory.hu dr.habil Békési László PhD
} 
A britek minden békés és háborús korszakban a legszínesebb érmekavalkáddal, éremképpel és pénzrendszerrel, pénzegységgel örvendeztették meg a világot -és a gyüjtőket-, ellenben a spanyolok mindenkor homogén, egységes államot sugalltak mindenhol ugyanolyan feliratú, súlyú és névértékü forgalmi pénzeikkel.

Az alaszkai oroszok és mai európai uniós francia szigetek az otthoni saját érméiket használták, illetve használják. Az oroszok rájöttek, hogy a korai papírpénz-forgalom képtelenség az időjárási szélsőségek hatása miatt Alaszkában, így rozmárbőr bankókat használtak. Az Euró érmek viszont európai viszonyok közé készültek és a karibi térség páraviszonyai között nagyon hamar korrodálódnak. Azaz pénzkibocsátás a földrajzi determinizmus által is meghatározott. Az éghajlat, a természeti viszonyok és a rendelkezésre álló alapanyagok akár az amortizáció mértékre is hatással vannak, de akár a nyersanyagot (lásd perui spanyol ezüstbányák, alaszkai rozmárvadászok) is meghatározzák.

Összességében elmondható, hogy az érmék () elemzésével reális képet kaphattunk a történelmi eseményekről. Az éremkibocsátás tökéletes indikátorként szolgált ahhoz, hogy leírhassuk egy anyaország és az általa megszerzett gyarmat kapcsolatának dinamikáját, mely minden esetben az anyaország következetes impériumépítő geostratégiájának részét képezte, még akkor is, amikor válságos időkben engedményeket tett kolóniájának megtartása és végső soron saját túlélése érdekében. A kísérlet, ahogy egyegy példán bemutattuk a bankjegyek és forgalmi bélyegek elemzésével is tovább gondolható. 